\title{
The Course Construction and Implementation of Entrepreneurship Simulation and Practice Based on Flipped Classroom
}

\author{
Wu Xiaofang ${ }^{a}$, Wang Gensheng ${ }^{b}$, Hu Xiangliang ${ }^{c}$, Huang Xuejian ${ }^{d}$ \\ Computer Practice Teaching Center, Jiangxi University of Finance and Economics, Nanchang, 330013, \\ China

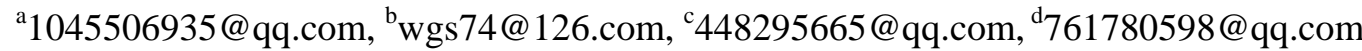

Keywords: Flipped Classroom; Teaching Reform; Practice Teaching;

\begin{abstract}
With the deepening of social education system reform, important changes have taken place in the teaching model. The traditional and infusing teaching methods can not meet the needs of education development of innovation and entrepreneurship in the new era. With the rapid development of the Internet information age, flipped classroom teaching is more and more widely used in teaching. In recent years, flipped classroom teaching has also achieved remarkable results in improving teaching quality and cultivating students' independent learning ability. In order to better achieve professional practice curriculum reform in our school, this article will take the curriculum as an example, the business simulation and practice in this turn is based on classroom teaching mode of the curriculum construction and start-up simulation and practice.
\end{abstract}

\section{Introduction}

Traditional classroom paradigm is formed under the background of the industrial revolution, to impart knowledge as the main process, the system of class teaching as the main form of teaching mode, its hull baht education represented by the "three centers", namely the center, teaching material, classroom teachers. With the coming of information era, the stability of the normal science was broken, the traditional classroom teaching paradigm is not adapt to the demand of the information age, so he formed on the background of information technology, the students' learning activities as the main characteristics of modern classroom teaching model[1]. Traditional teaching usually consists of two stages: knowledge imparting and knowledge internalization. The traditional classroom is to impart knowledge in the classroom and internalize and apply knowledge outside the classroom[2]. Flip the flip of the classroom teaching process is not only, also is the change of the teacher and the student role[3], realized the knowledge and knowledge internalization of two process, at the same time, which is associated with education concept, teaching content, teaching methods, teaching means and teaching evaluation of comprehensive changes[4].

\section{Teaching status}

The traditional classroom teaching mode is mainly dominated by teachers' classroom teaching, and the teaching methods of blackboard and chalk can no longer meet students' demand for knowledge [5]. In ordinary institutions of higher learning, most courses are taught using multimedia, students can only accept the traditional, infusive learning of teachers' class in a single and passive way. Although the main body of the class is students, in the actual teaching process, teachers still teach students more personal views and textbook contents, and students listen passively and receive the knowledge inculcated passively. The classroom lacks the exchange study with the student, the student study enthusiasm is low, the study efficiency is not high, the teaching reform actual effect is not obvious. By tilting the classroom teaching, the teacher can get chapters in advance knowledge, video, and micro class material on the platform, students can in extracurricular time by watching the video, such as micro class related materials to prepare. Before class, students can listen to lectures with learning questions, teachers can reduce the introduction of basic knowledge, class is no longer a common way to impart knowledge, and students can have more time to answer their questions. 


\section{Teaching Preparation}

The course "entrepreneurship simulation and practice" is a comprehensive and highly operational entrepreneurial practice course, students are required to have a strong foundation of professional knowledge and a high sense of innovation. In order to better organize flipped classroom teaching, the teaching preparation work will be carried out from the teaching team, teaching means and teaching resources.

\subsection{Establish a Cross-disciplinary Teaching Team to Enrich Teachers' Resources}

The course "entrepreneurship simulation and practice" combines the professional knowledge of financial management, human resource management, production management, marketing management and other related courses. According to the curriculum, in order to better complete the course teaching and improve the teaching quality, Formed from different departments and enterprises and nine units, more than 40 multi-disciplinary professional teachers team, formed by the foundation, the comprehensive experimental teaching of teachers and entrepreneurial training division of the high level, level 3 team structure of collaborative innovation, resource sharing. According to the different teaching division, the three-level team structure is divided into five roles: expert, lecturer, guide, coach and technical support.

\subsection{Various Teaching Methods and Abundant Teaching Methods}

This course makes full use of network teaching platform, virtual simulation experiment platform and mobile learning platform to carry out practical teaching process. Through the combination of three platforms, the course learning is combined online and offline、 combine the inside and outside of class self-study combined with coaching combined with individual teaching and team teaching , combining theory with practice - combine personal assessment with team assessment, carry out all-round course teaching, students can study anywhere and anytime according to their needs, which breaks the traditional classroom teaching, enriches the teaching methods and increases their interest in learning.

\subsection{Rich and Diverse Teaching Resources to Improve the Quality of Teaching}

Before the start of the course, the teaching course team will complete the construction of the online course "entrepreneurship simulation and practice" in advance on the online teaching platform, mainly includes the course syllabus, teaching courseware, teaching schedule, course description, curriculum implementation, curriculum assessment handbook, experimental template, knowledge point video and operation rules of experiment simulation platform data and other related content, students can preview before class according to their own needs, which improves the teaching quality.

\section{Teaching Implementation and Effect Analysis}

\subsection{Teaching Implementation}

The course "entrepreneurial simulation and practice" is a compulsory course for the second stage of teaching of economics and management major in our school. It has 32 hours in total, the beginning of the class is in July.

The implementation of teaching is divided into four steps:

Step one: understand operation rules and operation platform and set up an entrepreneurial team.

The teaching staff of each teaching class introduce the operation rules of the virtual commercial society and the operation of the virtual simulation experiment platform, let students have corresponding knowledge about operation rules and platform operation. The course is a course of teaching and practice in the form of an entrepreneurial team. Each team consists of four people, with five business positions, the general manager, the finance director, the purchasing director, the production director and the sales director.

Step two: learn professional management knowledge and simulate entrepreneurship. 
The expert teacher through the online live system, respectively to the team construction, enterprise strategic planning, marketing management and financial management of four professional knowledge points to carry out live instruction, and at the same time to focus on various problems which are easy to appear in the process of operation. Through the online live broadcast system, it has not only solved the problem of insufficient teaching staff in cross campuses, but also achieved the effect of sharing high-quality teachers resources.

Step three: the road speech defense link showing the management style

After eight years of simulated operation, the comprehensive performance of each teaching class has been determined. According to the content and nature of the course, the assessment criteria of show performance were formulated by the course group and experts,each team introduced the strategy of operation and deployment for eight years, and the experts made questions and comments. Finally, according to 1:3:6, one or two and three awards were selected and commended.

Step four: multiple assessment indicators and scientific evaluation

Curriculum evaluation is the baton of curriculum teaching, and different evaluation methods lead to different teaching methods. The course of entrepreneurship simulation and practice abandons the traditional evaluation method of teacher based and purely knowledge assessment, and constructs a multivariate process evaluation mechanism.

The multiple evaluation means that the students' achievement is composed of four parts. First, classroom performance accounted for $10 \%$; second, homework assessment accounted for $40 \%$. Third,the overall performance accounted for $30 \%$, that is the operation score of the virtual simulation platform; Fourth, the attendance accounted for $20 \%$.

\subsection{Implementation effect}

The experiment was completed in the two phase of the 2017 summer practical teaching process, with a total of 3153 students, 80 classes, 788 student teams, through the network teaching platform, the simulation experiment platform, the mobile learning platform and the online live broadcast system, the classroom overturn teaching has been realized, and the traditional teaching method has been broken. After the course, we investigate the teaching form, video resources, online communication, classroom discussion, practice and live link, and analyze the 369 questionnaires collected, about $80 \%$ of the students are satisfied with the form, video resources, online communication and classroom discussion of the flipping class teaching in the course of "entrepreneurship simulation and practice". At the same time, we randomly interviewed students in class, and the students expressed great recognition of the way of teaching reform.

\section{Summary}

With the vigorous development of the information age, it is an urgent need to promote the deep integration of the information technology and the classroom teaching by advocating the sharing of high quality learning resources together and promoting the deep integration of the information technology and classroom teaching. We need to make full use of the teaching informational software that is rich in functions and modern technology to achieve flipped classroom teaching. Through teaching information software, we have fully integrated the rich teaching resources of entrepreneurship simulation and practice course, giving full play to the students' learning subjectivity, improve the students' self-study ability, the reform of teaching methods and means has expanded the interaction between teachers and students.

\section{Acknowledgements}

This work was financially supported by the key reform project of higher education in Jiangxi Provincial Department of education (JXJG-17-4-2). 


\section{References}

[1] Jian Wang. The Essence of Flipped Classroom [J]. Journal of Higher Education, 2016, 37(08): 53-59. (In Chinese)

[2] Jinzhong Ma, Guohong Zhao, Peng Xu. Research on inverted classroom teaching practice based on campus network teaching platform[J].e-Education Research ,2014,35(12):99-103. (In Chinese)

[3] Yanli Liu. Flipping class: how to achieve an effective turnover [J]. China Higher Education, 2015, (19): 57-59. (In Chinese)

[4] Huijun Wang,Haili Wang. Study on the teaching mode of overturning classroom under multimodal field of view [J]. E-Education Research, 2015, (12): 70-76. (In Chinese)

[5] Yanhui Lin. Application of network teaching platform in the course of animal husbandry economic management [J]. Heilongjiang Animal Science and Veterinary Medicine, 2014(07): 171-173. (In Chinese) 